\title{
The Themes from A Curtain of Green
}

\author{
Song $\mathrm{Hu}$ \\ School of foreign languages, Dalian Jiaotong University, Dalian, 116021, China
}

Keywords: Welty; theme; social reality

Abstract: Eudora Welty is an excellent female writer in Southern American literature. This paper, along with her several stories as examples, analyze the themes in her first novel A Curtain of Green and Other Stories as well as the social reality which is reflected from these following themes.

Eudora Welty, born in a small town Jackson in the middle of Mississippi on April 13, 1903, whose mother was a teacher and father served with a key position in an insurance company during his lifetime. The rich and substantial middle-class family life provided good living conditions and the opportunity to receive higher education for Welty. As the first child in the family, she was given more care by her parents. In her living room, there was a "laboratory" established by her father, where there were various encyclopedias and dictionaries. Even when there was a shortage of money, her parents would squeeze money to buy books for their children, because they thought their children needed them during growth. Cultivated by such an environment, Welty became attached to books since childhood, and during her middle school ages, she published articles in some children's magazines. During study in University of Wisconsin, she studied British literature and European art history systematically. Later, she served as an advertisement writer and photographer in a radio station in her hometown. Such experience laid a solid foundation for her later literature creation. After becoming an adult, Welty put all her energies into creation. In 1936, she published her first short story Death of A Salesman, making her known in the literature circle. In 1941, she published her first collection of short stories Green Curtain. In addition to short stories, she also created five long novels, photo collections, memoirs and symposia etc. Her prestige spread from a poor area to the whole America, and even in the whole world. In her life nearly one century, she obtained many honors, like Pulitzer Prize, National Book Award and O Henry Novel Award.

Although Welty created several long novels, it is not difficult to find that short stories were still her "masterpieces" of creation. Green Curtain consisted of 17 short stories, each of was terse and forceful, but from the pretty things and small figures in these stories, we can find the simple local flavor, emotions of ordinary people and the real aspect of the southern society during the great economic reform. This paper is based on the short stories to explore the main thought contained in the novels of Welty and the social reality that she wanted to reflect.

\section{Topic I: Lonely inner world of figures}

In her lifetime, Welty did not get away from her birthplace, a small poor southern town in the basin of Mississippi River. This did not restrict her literature creation, but on the contrary, because of familiarity with the soil and people and things here, Welty could root her stories in her homeland more skillfully and depict the spiritual shock brought by the great economic reform to the people living in the small southern town for generations truthfully. Welty directly touched the inner heart of people with her pen, and depicted the lonely inner heart of the wandering people vividly.

Death of A Salesman was one of the important novels, it was this article more than 1000 words that made Welty concerned by the literature circle. The protagonist of the story was Bowman, who was an old salesman running around to support his life. For 14 years, he had always been running around to sell leather shoes for his boss. He had no home, and even if he had influenza, he had to live in the hotel; no one concerned him, so in his inner heart, the only sustenance was his dead grandmother and the wide and soft bed in his grandmother's room. Due to sales of leather shoes for years, he became a sales machine, with solitary character and cold to people. Even when he lost his way, he was unwilling to seek for help from others. In his eyes, there was only material an money transaction between people, and family affection and love were just empty words. Therefore, when his car fell into a ditch and he had to seek help from a household, seeing that although the couple in 
the household were poor but loved each other, he suffered great shock in his inner heart, and he was surprised to the tolerance between couple and warmness to a stranger. Finally, he gave all his money to this couple and left with a broken heart, falling on the ground.

The heroine in the story Why I Lived in Post Office told her lonely inner heart in the form of monologue. She was a post woman in a small post office in Mississippi. At the beginning of the story, the heroine complained endlessly. She complained that her younger sister returned home and broke her quiet and harmonious life after divorce; she complained that her younger sister deliberately broke her good marriage with Mr. Whitaker when she was about to get her love, and that her younger sister slandered for her strange body shape, and complained that her younger sister was spoiled just because of 12 months younger than her... Even if her younger sister opened the window upstairs, she was also full of complaint. She complained that all her family members took the sides in her younger sister and objected her. Finally, she selected to live in the post office. Welty presented such a farce with her humorous language, but after laughter, we will feel bitter. Superficially, we see a small cutting, showing-off and even moonstruck post woman, but actually, we can feel her thirst for love in her lonely inner heart. She was thirst to get love between men and women, but her love was broken by her younger sister Stella's slander; she was thirst to get solicitude and concern from family members, but in vain. Perhaps because she was desperate completely, she selected to leave home, even she was strongly objected by her family members, she was also thirst to hunt for the happiness belonging to herself.

\section{Topic II: Spreading breath of death}

In the American southern literature works with diversified topic creation and unique style, the topic of death has always been pursued by many southern writers, from William Faulkner to Flannery O'Connor, without exception. In their works, they usually used death to present their thinking over the society and moral ethics and sentiment to life, so did Eudora Welty. Looking at the whole life of Welty, it is not difficult to find that her creation thought to the topic of death did not only have a fundamental social source, but was also influenced by her family factors.

In America in the 1830s, the conservative and backward south experienced the baptism of capitalist industrial civilization and the great economic depression. The great change in economic system brought a deadly strike to the heart of ordinary people. People did not only require to experience the change of lifestyle, but also the change of thinking mode and even the concept of moral ethics. No doubt, it was death that was the best liberation method for the small figures living in the crack. At that moment, Welty, who was just mature and had always living in the family care, should also accept the sudden family change. In 1931, her father died of leukemia and because of this, her mother was depressed. Just like what she wrote in The Starting Point of A Writer, "such behavior of the doctor means the death of father". "From then on, my mother did not recover mentally any longer. Although she lived more than 30 years longer and suffered from more frustration, she had never stopped blaming herself. She had always thought it was her responsibility not to save my father." (Beginning, 93). Such life experience, although seeming to be painful for Welty, increased materials for her novel creation, i.e. blending the life tragedy into the literature works. Hence, in Green Curtain and Other Stories, we see the figure images of using "death" to seek for spiritual liberation or tortured by “death".

The heroine in Green Curtain was young widow. Mrs. Larkin, who had conjugal love with her husband witnessed in person that her husband was crushed to death by a big tree falling in her garden. From then on, she lived in the bitterness of losing relative irresistibly. She confined herself in her own garden, worked unremittingly in the garden and attempted to liberate the heart bitterness in a busy method and isolate her contact with the outside world with the dense flowers and trees. She hated herself for incapability of preventing her husband's death, for the God's not hearing her praying and in despair, she even challenged the ineluctable life and death. So she lifted her hoe and wanted to kill a black boy who was working hard, but a heavy rain came appropriately, preventing the occurring of a tragedy like a powerful hand, and washing away Mrs. Larkin's impulse of attempting to resist against life and death. When fell in a green curtain woven by herself, we can 
clearly see that this poor woman would still continue her lonely life in the green natural barrier.

Clytie was a tragic story. The heroine Clytie was diligent and capable, who was busy in cooking for the family, "Clytie cooked three meals in the furnace, and each people would have different things with three pallets and she also had to present the meals upstairs according to the right order". (Welty, 164) Even if she served each person in the family, she also had to bear her older sister's scold and brother's complaint. No one concerned Clytie, and there was only demand and scold from her father, brother and sister. She tried to support the declined family with her hands full of wrinkles, but one day when she suddenly saw her ugly face in a broken water barrel, she was shocked. Facing the suppressed life, this poor woman selected "death" to liberate herself, perhaps this was her only choice.

In addition to the above two works, the topic of "death" also appeared in may stories of Welty. For example, in Death of A Salesman, Bowman, ran around for years in order to seek for livelihood, and seemed to be very old just at the middle age. Without friends and even without home, suddenly he died of heart disease on the roadside. Another example, in Flower to Majulie, the hero Howard was unemployed and his wife was pregnant, the life pressure made him nearly collapsed. Although he was a modest and polite good man keeping on the rails, she had to wander without purpose to sustain his livelihood; although she deeply loved his wife, he generated an illusion because of spiritual suppression, and killed his wife in an absent-minded state, but he did not know it at all. Tasting stories full of the breath of death, we have to deeply admire Welty for her meticulous writing. In the ruthless industrial times, ordinary people could not master their destiny and had to lead such a miserable and despairing life.

\section{Topic III: Love and solitude-eternal theme of life}

Although Welty was skilled at depicting the unfortunate suffering of small figures in life, we can also experience the love and solitude between people from some of her works, especially the affection of mutual help and relief in time of poverty among the family members. Welty lived in a happy and harmonious life, whose parents loved each other. As she was the first child in her family, her parents gave her endless love and solitude. For Welty, "home" had always been the warmest harbor, even after her father passed away and she had to run around for the family livelihood, her heart had always rested on "home", and on the land where she was born and cultivated. Welty loved her hometown and had never left nearly in her whole life; she loved her family members, so she rose to fame, facing her seriously sick mother and younger brother, she selected to give up, and devoted herself taking care of the patients. When her mother and younger brother left her successively, lonely Welty raised her pen again and became a focus in the comment circle again. In her works, we can feel her eulogizing for love between people and affection in family members.

Familiar Road was a very excellent work, which made Welty really move the whole literature forum in America and because of it, Welty won her first O Henry Award. The heroine of the story Phoenix was an old black woman, who was diligent and kind. Although experiencing the suffering of life, she had a very strong willpower. The old woman lived in a remote mountainous area, in order to seek for medicine for her sick grandson, she must overcome many difficulties, animals and insects in the mountain, the bumpy mountainous road, thorny fences, a big black dog and threat of white hunters etc. But this short and wrinkly old woman et moving. Even if facing the fun of hunters, she was not afraid at all. What she bore was her love to her grandson who was not healed after long treatment, and the great affection was reflected vividly in this story.

The love and solitude between people can touch everything in the world, still remember Bowman in Death of A Salesman. Although 14 years' running around made him become cold and dissocial, when he lost his way and his car fell into a ditch and he had to seek for help from others, and when he saw although the farmers saving him were as poor as a church, the couple still loved each other and helped such a stranger like him without stint, his solid body was thawed, and his thirst for love in his inner heart was stimulated. From the famer couple whom he did not look upon at all, he felt that only love and solitude was the root for survival of people.

\section{Conclusion}


Eudora Welty blended the soil and surrounding people that she was familiar with into her works, and created thought-provoking stories with the unique meticulous writing style of female. She vividly depicted the life and death, happiness and sorrow of ordinary people in the cold industrial times on the paper. Welty was skilled at the thorough understanding to figures' inner heart, and was good at using the trivial things in daily life to express the truth of life. It is from these terse and forceful stories, simple and refined languages and extraordinarily usual story plots that we experience the main idea reflected y Welty and her deep inspiration to life.

\section{References:}

[1] Eudora Welty. A Curtain of Green and Other Stories (M). Orlando: Harcourt Brace Jovanovich, Publishers, 1979.

[2] Eudora Welty. One writer’s Beginnings. Havard University Press 2000.

[3] Wang Renli, Welty and Her Novels (A), On Contemporary American Novelists (C). Beijing: China Social Sciences Publishing House, 1987

[4] Yang Renjing, American Literature History in the $20^{\text {th }}$ Century (M), Qingdao: Qingdao Press, 1999

[5] Cao Li, Welty and her Short Stories (1), Foreign Literature, 1998 (2)

[6] Fu Jingchuan, America Novel History in the $20^{\text {th }}$ Century (M), Changchun: Jilin Education Press, 1996 